International JOURNAL OF MULtidisciplinaRy Research AND ANALysis

ISSN(print): 2643-9840, ISSN(online): 2643-9875

Volume 04 Issue 05 May 2021

DOI: 10.47191/ijmra/v4-i5-05, Impact Factor: 6.072

Page No.- 530-536

\title{
Determination of Aquifer Parameters Using Theis Method in Malamawi Island, Isabela City, Basilan, Philippines
}

\author{
Alejandro A. Jalil ${ }^{1}$, Roger A. Luyun, Jr. ${ }^{2}$, Aurelio A. Delos Reyes, Jr. ${ }^{3}$, Victorino A. Bato ${ }^{4}$ \\ ${ }^{1}$ Basilan State College, College of Agriculture and Fisheries, Santa Clara Campus, Lamitan City, Basilan, Philippines \\ ${ }^{2,3}$ Land and water Res. Div., Inst. of Ag. Eng'g, College of Engineering and Agro-industrial Technology, University of the Philippines, \\ Los Banos, Philippines \\ ${ }^{4}$ Department of Soil Science, College of Agriculture, University of the Philippines, Los Banos, Philippines
}

ABSTRACT: The study aims to determine the hydrologic properties of an aquifer of Malamawi Island in terms of transmissivity, storage coefficient, and specific discharge using the Theis method. The study was conducted in March of 2015. The 4 inches 2 boreholes are drilled in two different locations (Diki and Santa Barbara villages) to identify the lithologic properties. A pumping test was performed for forty-five (45) minutes and, drawdowns are observed from the observation well. The shallow aquifer is confined with a transmissivity of $1.70 \mathrm{~m}^{2} / \mathrm{d}$, storage coefficient of 0.001012 , and specific discharge of $6.53 \mathrm{~m}^{2} / \mathrm{d}$.

KEYWORDS: Malamawi, Shallow Groundwater, Basilan, Theis, Isabela City

\section{INTRODUCTION}

Assessing aquifer permeability is one of the most important aspects of any groundwater study (Sun, 2018). Two parameters, transmissivity $(T)$ and storage coefficient $(\mathrm{S})$ control the movement and extraction of groundwater in the geological formations (Birpinar, 2003; Naderi, 2019). The transmissivity is that the product of the hydraulic conductivity and therefore the saturated thickness of the aquifer. It is a measure of the amount of water that can be transmitted horizontally through a unit width by the pack saturated thickness of the aquifer under a hydraulic gradient of 1 (Strerrett, 2007; Sun, 2018). The hydraulic parameters conductivity, and transmissivity (Cooper and Jacob, 1946) of the aquifers can be determined through pumping test analysis (Maréchal et al., 2008; Dausse et al., 2019). However, it can also be analyzed by several conventional and computerbased methods (Kruseman and De Ridder, 1991; Birpinar, 2003). Analyzing the data of unsteady pumping test conducted in the aquifer is one of the main ways for estimating aquifer parameters such as transmissivity and storage coefficient, which are main parameters for evaluation and exploitation of groundwater resources (Theis, 1935; Hongfei \& Jianqing, 2012) According to (Dausse et al., 2019), at the local scales, crosshole hydraulic tests, such as pumping tests, can be used to identify the flow pattern to provide information on reservoir geometry, additionally to its hydraulic properties (Gringarten, 2008). At the regional scale, water level monitoring in several observation wells appropriately distributed across the system are often used, as an example, to spot potential compartments under different hydrological conditions (Guihéneuf et al., 2014). An imbalance between groundwater pumping and natural recharge occurs when the aquifer suffers from steep declines thanks to groundwater exploitation. Reducing the current extraction and providing artificial recharge in specific parts of the aquifer stabilize and reverse the decline in groundwater levels while meeting the water demands for the Island (Campos et al.,2014; Elrawy et al., 2021).

The people on the Island have solely relied on groundwater for domestic and agricultural purposes. The aquifer parameters got to establish for future assessment of groundwater sustainability to support the evergrowing population of the Island. Therefore, this research study aims to estimate transmissivity, storage coefficient, and specific discharge of Malamawi Island aquifer, using the Theis superimposition method. This method uses a graphical procedure with type curve matching (Leng \& Yeh, 2003; Li et al., 2014; Yeh \& Huang, 2005; Ha et al., 2020; Chen et al.,1999), and identified through fitting the measured drawdown data to reference data. Furthermore, the estimated parameters can predict the drawdown (Shen et al., 2015; Ha et al., 2020) and essential for effective water management and protection (Jeong, 2001; Edmunds et al., 2002; Perea and RodriguezRodriguez, 2009; Dragon, 2021). 


\section{MATERIALS AND METHODS}

\section{Study area}

Malamawi Island (Figure 1a) is about $300 \mathrm{~m}$ from the main island of Basilan. It has a total delineated area of about 947 hectares. The island consists of seven different villages and located between 6 6 $42^{\prime} 46^{\prime \prime} \mathrm{N}$ and $6^{\circ} 44^{\prime} 45^{\prime \prime} \mathrm{N}$ latitudes, $121^{\circ} 56^{\prime} 24^{\prime \prime} \mathrm{E}$, and $121^{\circ} 58^{\prime} 23^{\prime \prime}$ E longitudes. The general elevations ranged from $5 \mathrm{~m}$ to $103 \mathrm{~m}$ above sea level while and slopes ranged from $3 \%$ to $30 \%$. The island has a current population of 13,859 most of them build their houses along the shoreline.

Land use on the island is mainly agricultural, with most areas planted to coconut with few mangos, citrus, and rubber trees. The root crops and vegetables are regularly planted on small scale on the hilly portions. The area mainly consists of medium to heavy texture soil types. The island has a type III climate classification, where the seasons are not very pronounced, relatively dry from November to April, and wet during the rest of the year (Bangsamoro Development Agency, 2016). The annual mean temperature and precipitation are $26.6^{\circ} \mathrm{C}$ and 1,100 mm, respectively (Bangsamoro Development Agency, 2016, Jalil et al., 2020). Test Well

A test well (Figure 1b) was drilled for well logging and the determination of the aquifer hydrologic properties in the study area through a pumping test. It has a $10.16 \mathrm{~cm}$ diameter hole with a depth of $24.39 \mathrm{~m}$. The descriptions of the pumping test data of the test well are given in table 1.
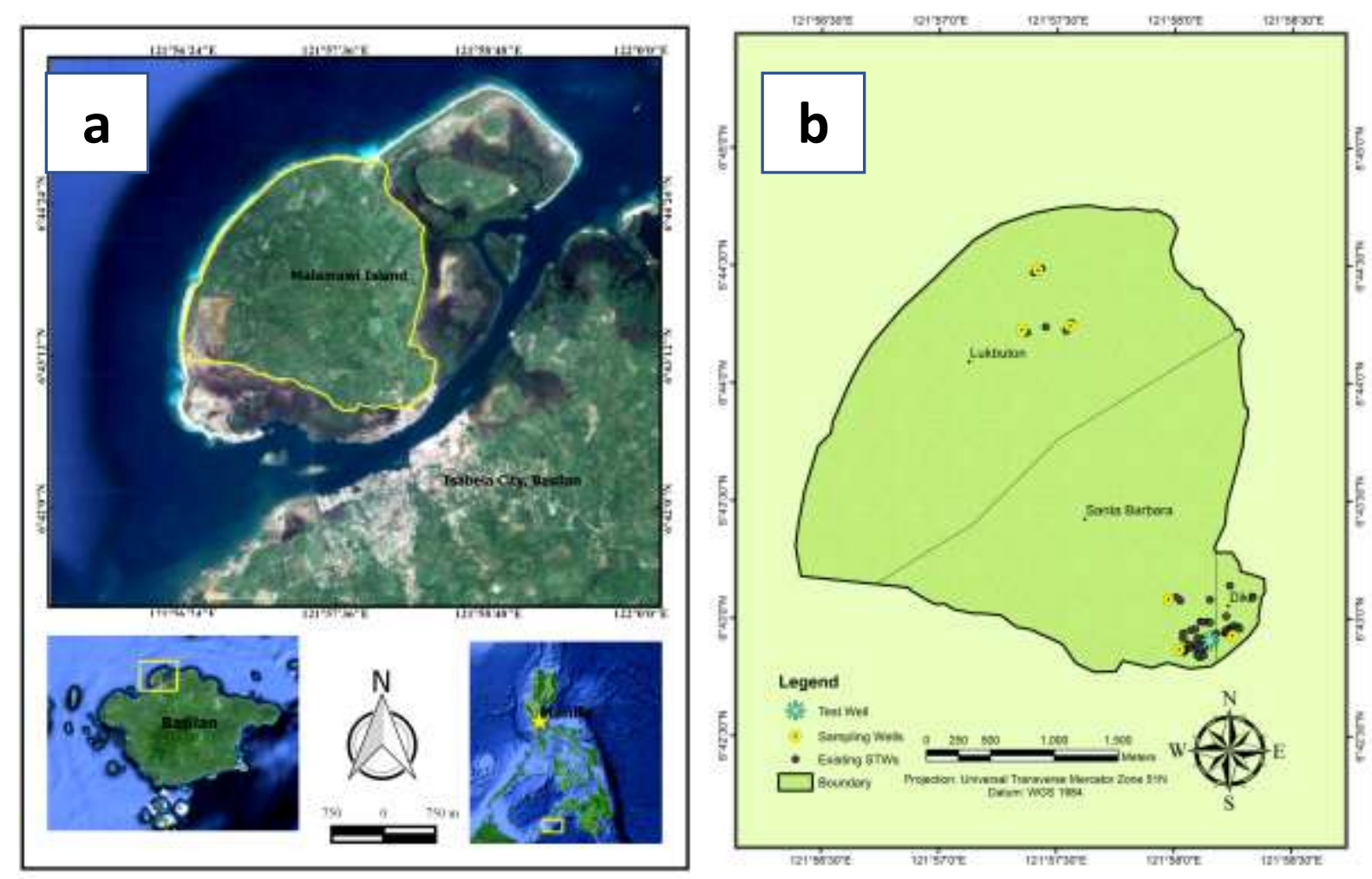

Figure 1. Location map, a). Study area (Source: Google Earth, 2015) , b). Test Well, of Malamawi Island, Isabela City, Basilan

\section{Lithologic Properties}

The lithologic properties of the aquifer are established through well logging conducted in the study area. The local drillers

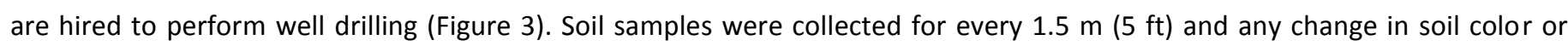
hardness and placed in labeled transparent plastic bags. Textural analysis of each sample was performed using locally fabricated sieves of different diameters/sizes. As a result, the depth and thickness of the aquifer and confining layers are then determined. 
Determination of Aquifer Parameters Using Theis Method in Malamawi Island, Isabela City, Basilan, Philippines

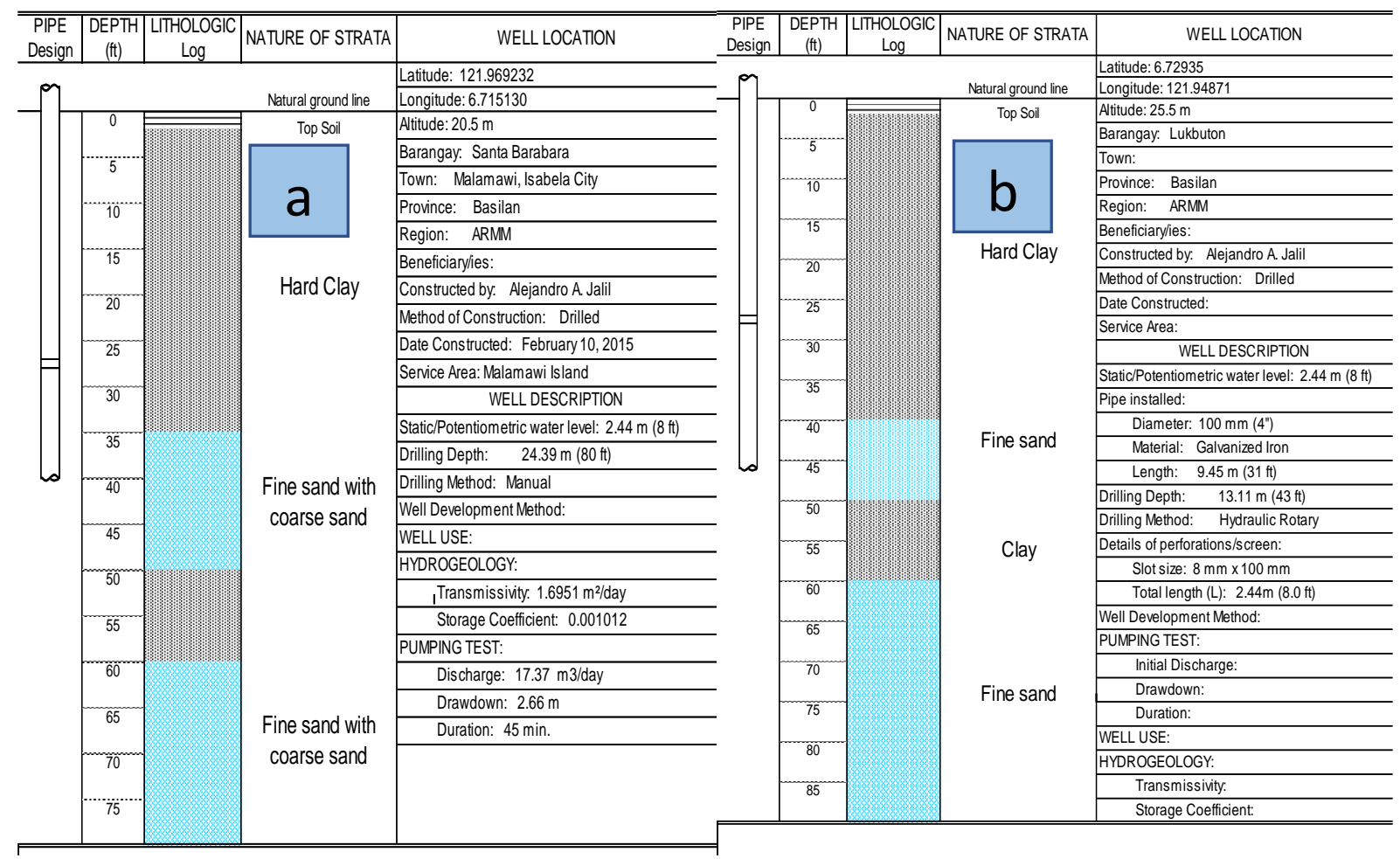

Figure 2. Well Log at, a). Diki Village, b). Santa Barbara Village, Malamawi Island, Isabela City, Basilan, Philippines

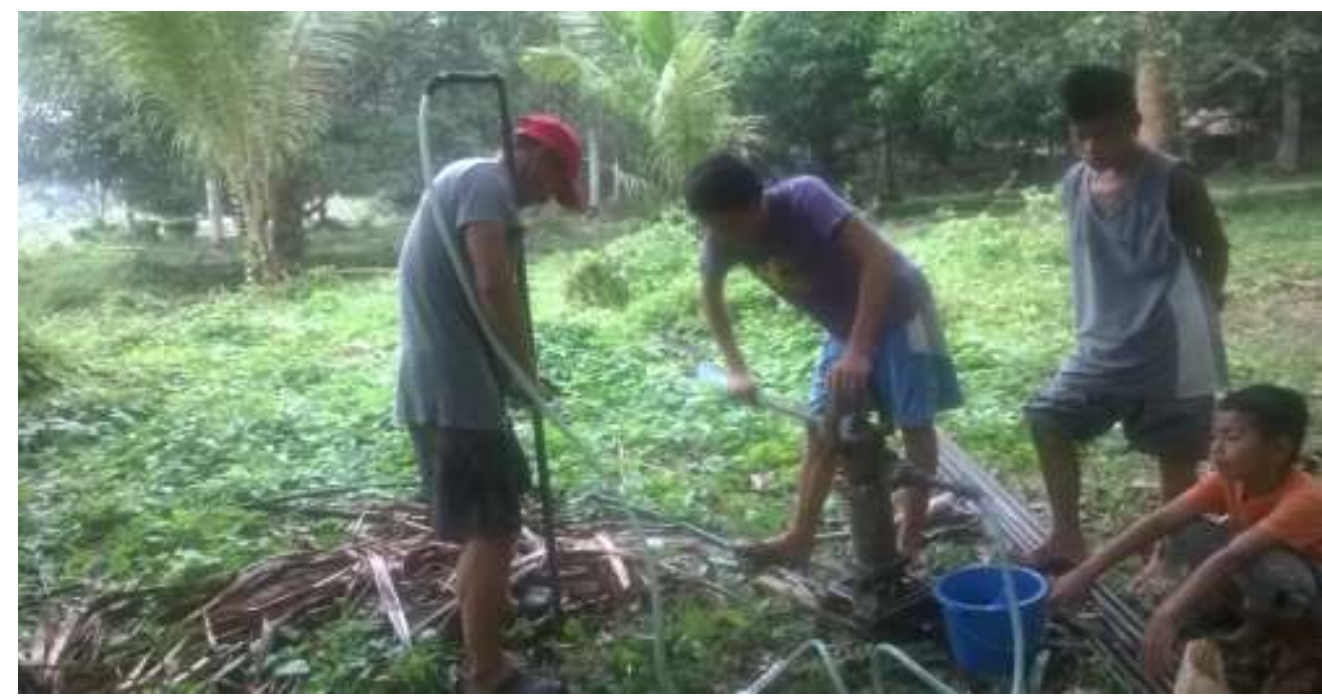

Figure 3. Local drillers using locally fabricated drilling rig during the actual manual drilling for well logging in the study area

Table 2. Time-Drawdown Data

\begin{tabular}{|l|l|l|}
\hline \multirow{2}{*}{ Time (min) } & Drawdown (M) \\
\cline { 2 - 3 } & Pumping Well & Observation Well \\
\hline 5 & 1.194 & 0.044 \\
\hline 10 & 1.410 & 0.181 \\
\hline 15 & 1.689 & 0.380 \\
\hline 20 & 2.077 & 0.472 \\
\hline 25 & 2.147 & 0.591 \\
\hline 30 & 2.420 & 0.673 \\
\hline 35 & 2.566 & 0.698 \\
\hline 40 & 2.604 & 0.717 \\
\hline 45 & 2.655 & 0.724 \\
\hline
\end{tabular}




\section{Determination of Aquifer Parameters Using Theis Method in Malamawi Island, Isabela City, Basilan, Philippines}

\section{Hydrologic Properties}

The hydrologic properties of the aquifer are determined through the conduct of a pumping test. Pumping was done at the test well employing a constant discharge, and drawdowns were monitored simultaneously at the observation wells at specific time intervals. The transmissivity and storage coefficient of the aquifer of the Island are determined using the Theis method of superimposition.

\section{Transmissivity and storage coefficient}

Transmissivity refers to the fastest at which water is transmitted through a unit width of the aquifer under a unit hydraulic gradient. The storage coefficient could also be defined because the volume of water that an aquifer releases from or takes into storage per unit area of aquifer per unit change within the component of head normal thereto surface. These parameters were computed using the Theis method.

$$
\begin{aligned}
& \mathrm{T}=\frac{6.9 Q}{s} \mathrm{~W}(\mathrm{u}) \\
& \mathrm{Sc}=\frac{4 T u}{r^{2} / t}
\end{aligned}
$$

Where $\mathrm{T}, Q, s, \mathrm{~W}(\mathrm{u}), \mathrm{Sc}, \mathrm{r}$, and $\mathrm{t}$ are transmissivity in $\mathrm{m}^{2} /$ day, well discharge in liters per seconds, drawdown in meter, well function, storage coefficient, dimensionless, distance of observation well from production well in meter, and time since pumping began in days, respectively.

\section{Measurement of static water level and drawdown}

The static water level in the test well was measured before the start of the pumping test. It was measured from the natural ground surface as (reference point) through the use of an improvised groundwater level probe. The drawdown at the observation well was measured at different time intervals until equilibrium or when the drawdown became stabilized. Drawdown was computed as the difference between the static water level and the water level at a certain time during pumping expressed in meters below ground surface (mbgs).

\section{Determination of specific discharge}

Specific discharge has defined as the rate of discharge of groundwater per unit area of a porous medium measured at a right angle to the direction of flow. Similarly, it is a rate of discharge of well per unit drawdown. This is computed using the equation (Todd, 1980).

$$
\mathrm{Q}_{\mathrm{d}}=\left(\frac{Q}{s}\right)
$$

Where the $Q_{d}, Q$, and $s$ are specific discharge of a pumping well in $\left(\mathrm{m}^{3} / \mathrm{m}\right.$-day), constant pumping rate in ( $\mathrm{m}^{3} / \mathrm{day}$, and drawdown of pumped well in $(m)$, respectively.

\section{RESULTS AND DISCUSSION}

\section{Test Well}

The test well is located within the clustered shallow wells (Figure 1b) and has a static piezometric water level of $3.66 \mathrm{~m}$ below the ground surface. The water level is not affected by sea-level fluctuations caused by tides. During the pumping test operations, pumping of the neighboring wells within a $50 \mathrm{~m}$ radius from the test well was not allowed. The results of computed hydrologic properties of the test well are assumed to represent the properties of the whole aquifer in the area because based on the two well logs the aquifer is most likely uniform which could have similar lithologic and hydrologic properties.

\section{Stratigraphy}

The soil profile in the study area was established through the conduct of well logging in two barangays. The well logs in Santa Barbara and Lukbuton are shown in Figures $2 a$ and $2 b$, respectively. The soil profiles in both locations showed confined aquifers overlain by thick hard clay and a clay layer in between. The aquifers are composed of fine and coarse sands. This is indicative that the aquifers in both locations are hydrologically connected.

\section{Transmissivity and Storage Coefficient}

A pumping test was done on the test well to determine the aquifer's hydrologic properties. The pumping test data were presented in Table 1. The transmissivity and storage coefficient was found to be $1.70 \mathrm{~m}^{2} / \mathrm{d}$ and 0.001012 respectively using Theis method of superimposition (Figure 4). The computed transmissivity was very low. In fact, the drawdown was so abrupt during the conduct of the pumping test. However, these calculated values of transmissivity and storage coefficient were within the range of values for fine sand. Detailed computations of these hydrologic parameters were presented in Appendix Table 5. 
Determination of Aquifer Parameters Using Theis Method in Malamawi Island, Isabela City, Basilan, Philippines

Table 1. Pumping Test Data of the test well in the area March 2015

\begin{tabular}{|l|l|l|}
\hline Particulars & Test Well & Observation Well \\
\hline Static Water Level, $\mathrm{m}$ & 3.69 & 3.69 \\
\hline Well diameter, inch & 4 & 3 \\
\hline Distance from Test Well, $\mathrm{m}$ & & 6.809 \\
\hline Test Well Discharge, li/s & .201 & \\
\hline
\end{tabular}

Table 3. Computation of storage coefficient and transmissivity given the required values of parameters

\begin{tabular}{|l|l|l|l|l|l|}
\hline Drawdown, $\mathbf{s}$ & $\mathbf{r}^{2} / \mathbf{t}$ & $\begin{array}{l}\text { Well } \\
\text { Function } \\
\mathbf{W}(\mathbf{u})\end{array}$ & $\mathbf{u}$ & $\begin{array}{l}\text { Storage } \\
\text { Coefficient } \\
(\mathrm{Sc})\end{array}$ & $\begin{array}{l}\text { Transmissivity } \\
(\mathbf{T})\end{array}$ \\
\hline$(\mathbf{m})$ & $\mathrm{m}^{2} /$ day & Unitless & Unitless & Dimensionless & $\mathbf{m}^{2} /$ day \\
\hline 0.18 & 6,700 & 0.22 & 1 & 0.001012 & 1.70 \\
\hline
\end{tabular}

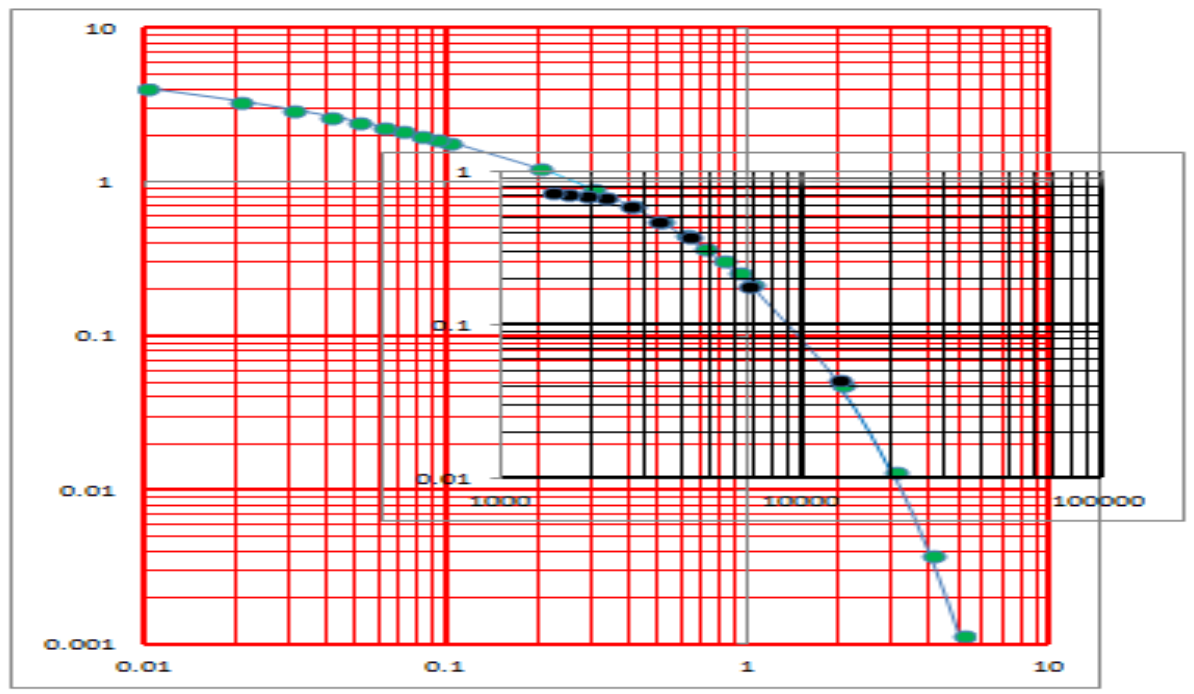

Figure 4. Superimposition of data curve to the type curve using Theis method

\section{Specific Discharge}

The specific discharge of the test well in the study area was computed to be $6.53 \mathrm{~m}^{2} / \mathrm{d}$ at a given discharge and drawdown of $17.37 \mathrm{~m}^{3} / \mathrm{d}$ and $2.66 \mathrm{~m}$, respectively. The value indicates the total area reached by flowing water within the aquifer per day.

\section{CONCLUSION}

Lithologic properties of the aquifers in the study area were determined through well logging while the hydrologic properties were obtained through pumping test of a test well located at Santa Barbara. The study area is underlain by a confined aquifer with a computed transmissivity of $1.70 \mathrm{~m}^{2} / \mathrm{d}$ and storage coefficient of 0.001012 using the Theis method of superimposition. The specific discharge of the test well in the study area was computed to be $6.53 \mathrm{~m}^{2} / \mathrm{d}$.

\section{ACKNOWLEDGEMENTS}

I would like to acknowledges the Commission of Higher Education (CHED), Philippines, for the scholarship grant in my master's degree program at the University of the Philippines and funding this research study. Likewise, countless thanks and gratitude to a former president of Basilan State College, Dr. Nasser A. Salain, for his motivation and grant of my schooling.

\section{REFERENCES}

1) Bangsamoro Development Agency. (2016). Comprehensive Capacity Development Project for the Bangsamoro Development Plan for the Bangsamoro Final Report Sec.

2) Birpinar, M. E. (2003). Aquifer Parameter Identification. Water SA, 29(3), 1197-1209.

https://doi.org/10.1061/jyceaj.0004416 


\section{Determination of Aquifer Parameters Using Theis Method in Malamawi Island, Isabela City, Basilan, Philippines}

3) Campos-Gaytan JR, Kretzschmar T, Herrera-Oliva CS. Future groundwater extraction scenarios for an aquifer in a semiarid environment: case study of Guadalupe Valley Aquifer, Baja California, Northwest Mexico. Environ Monit Assess 2014; 186:7961-85. doi: https://doi.org/10.1007/s10661-014-3980-6.

4) Chen Congxi, Lin Min. 1999, Groundwater dynamics (in Chinese), Wuhan, China University of Geosciences Press, pp.70122

5) Cooper, H.H., Jacob, C.E., 1946. A generalized graphical method for evaluating formational constants and summarizing well field history. Transaction American Geophysical Union 27, 526-634.

6) Dausse, A., Leonardi, V., \& Jourde, H. (2019). Hydraulic characterization and identification of flow-bearing structures based on multi-scale investigations applied to the Lez karst aquifer. Journal of Hydrology: Regional Studies, 26(November), 100627. https://doi.org/10.1016/j.ejrh.2019.100627

7) Dragon, K. (2021). Identification of groundwater conditions in the recharge zone of regionally extended aquifer system with use of water chemistry and isotopes (Lwowek region, Poland). Journal of Hydrology: Regional Studies, 34(July 2020), 100787. https://doi.org/10.1016/j.ejrh.2021.100787

8) Edmunds, W., Carrillo-Rivera, J., Cardona, A., 2002. Geochemical evolution of groundwater beneath Mexico City. J. Hydrol. 258 (1-4), 1-24. Fetter,

9) El-rawy, M., Makhloof, A. A., Deep, M., \& Galal, M. (2021). Groundwater management of quaternary aquifer of the Nile Valley under different recharge and discharge scenarios: A case study Assiut. Ain Shams Engineering Journal, xxxx. https://doi.org/10.1016/j.asej.2021.02.023

10) Gringarten, A.C., 2008. From straight lines to deconvolution: the evolution of the state of the art in well test analysis. Spe Reserve. Eval. Eng. 11, 41-62. https://doi.org/ 10.2118/102079-ms.

11) Guihéneuf, N., Boisson, A., Bour, O., Dewandel, B., Perrin, J., Dausse, A., Viossanges, M., Chandra, S., Ahmed, S., Maréchal, J., 2014. Groundwater flows in weathered crystalline rocks: impact of piezometric variations and depth-dependent fracture connectivity. J. Hydrol. (Amst) 511, 320-334. https://doi.org/10.1016/j.jhydrol. 2014.01.061.

12) Ha, D., Zheng, G., Zhou, H., Zeng, C., \& Zhang, H. (2020). Estimation of hydraulic parameters from pumping tests in a multiaquifer system. Underground Space (China), 5(3), 210-222. https://doi.org/10.1016/j.undsp.2019.03.006

13) Hongfei, Z., \& Jianqing, G. (2012). Chaotic Sequence Optimization Algorithm for Estimation of Aquifer Parameters from Data of Pumping Test. Procedia Environmental Sciences, 12(Icese 2011), 528-536. https://doi.org/10.1016/j.proenv.2012.01.313

14) Jalil, A., Luyun, Jr, R., Delos Reyes, Jr, A., \& Bato, V. (2020). ASSESSMENT OF GROUNDWATER QUALITY FOR IRRIGATION AT MALAMAWI ISLAND, BASILAN, PHILIPPINES. Jurnal Penelitian Pengelolaan Daerah Aliran Sungai, 4(2), 187-200. https://doi.org/10.20886/jppdas.2020.4.2.187-200

15) Jeong, C.H., 2001. Effect of land use and urbanization on hydrochemistry and contamination of groundwater from Taejon area, Korea. J. Hydrol. 253 (1-4), 194-210. Lasagna,

16) KRUSEMAN GP and DE RIDDERNA (1991) Analysis and Evaluation of Pumping Test Data. ILRI Publ. 47, 2"^Ad., Wageningen, The Netherlands

17) Leng, C. H., \& Yeh, H. D. (2003). Aquifer parameter identification using the extended Kalman filter. Water Resources Research, 39(3), 1062.

18) Li, P., Qian, H., \& Wu, J. (2014). Comparison of three methods of hydrogeological parameter estimation in leaky aquifers using transient flow pumping tests. Hydrological Processes, 28(4), 2293-2301.

19) Maréchal, J.-C., Ladouche, B., Dörfliger, N., Lachassagne, P., 2008. Interpretation of pumping tests in a mixed flow karst system. Water Resour. Res. 44, W05401. https://doi.org/10.1029/2007WR006288.

20) 10. Naderi, M. (2019). Estimating confined aquifer parameters using a simple derivative-based method. Heliyon, 5(10), e02657. https://doi.org/10.1016/j.heliyon.2019.e02657

21) 11. Sun, K. (2018). Formulating surrogate pumping test data sets to assess aquifer hydraulic conductivity. Journal of Hydrology X, 1, 100004. https://doi.org/10.1016/j.hydroa.2018.100004

22) Perea, R., Rodriguez-Rodriguez, M., 2009. Water quality for different uses in the main groundwater bodies of the Guadalquivir River Watershed, Atlantic Basin, Spain. Environ. Earth Sci. 59 (1), 75-86.

23) Shen, S. L., Wu, Y. X., Xu, Y. S., Hino, T., \& Wu, H. N. (2015). Evaluation of hydraulic parameters from pumping tests in multi- aquifers with vertical leakage in Tianjin. Computers and Geotechnics, 68, 196-207.

24) Strerrett, R.J., 2007. Groundwater and Wells. Johnson Screens, New Bringhton, MN

25) Theis, C. V. 1935, The relation between the lowering of the piezometric surface and the rate and duration of discharge of a well using groundwater storage. Trans. of American Geophysical Union 16: pp.519-52, 
Determination of Aquifer Parameters Using Theis Method in Malamawi Island, Isabela City, Basilan, Philippines

26) Todd, D.K. 1959. Groundwater Hydrology. John Wiley and Sons. New York.

27) Yeh, H. D., \& Huang, Y. C. (2005). Parameter estimation for leaky aquifers using the extended Kalman filter, and considering model and data measurement uncertainties. Journal of Hydrology, 302(1/2/3/4), 28-45. 